\begin{tabular}{|c|c|c|c|c|}
\hline & & Journal : Small 11205 & \multirow{2}{*}{$\begin{array}{l}\text { Dispatch : 24-11-2017 } \\
\text { LE }\end{array}$} & \multirow{2}{*}{$\begin{array}{l}\text { Pages: } \mathbf{2 1} \\
\text { TYPESET }\end{array}$} \\
\hline & & Article No. : 1776 & & \\
\hline & & MS Code : SOCI-D-17-00026 & CP & DISK \\
\hline
\end{tabular}

\title{
3 The Standard of Living of the Workers in a Spanish 4 Industrial Town: Wages, Nutrition, Life Expentancy 5 and Heigth in Alcoy (1870-1930)
}

\author{
6 José Joaquín García-Gómez ${ }^{1,2}$ (D) Antonio Escudero Gutierrez ${ }^{3,4}$
}

7 Accepted: 21 October 2017

8 (C) Springer Science+Business Media B.V. 2017

9 Abstract Many studies carried out on the evolution of the standard of living have shown

10 that it is advisable to use several indicators as there is no single indicator that reflects all of

11 the dimensions of well-being or that does so without incurring value judgements. Fol-

12 lowing this line of research, this study examines the well-being of the workers of Alcoy

13 during the industrialisation process using four indicators: real wages, nutrition, life

14 expectancy and height. As happened in other European industrialized regions some dec-

15 ades before, between 1870 and the end of the nineteenth century we can observe a "puzzle"

16 as two indicators point to an increase in the standard of living and the other two reveal the

17 opposite. The "puzzle" later disappears because from the beginning of the twentieth

18 century to 1930 the four indicators show that well-being increased.

19 Keywords Industrialization $\cdot$ Welfare $\cdot$ Workers $\cdot$ Health reform $\cdot$ Spain

20 JEL Classification $\mathrm{N} 3 \cdot \mathrm{J} 1 \cdot \mathrm{N} 9 \cdot \mathrm{H} 4$

A1 The original version of this article was revised: The section 5 was missed out and the Conclusions part was

A2 published incorrectly. Now the section 5 is included and correct Conclusions section has been provided in

A3 this erratum.

A4 $\bowtie$ José Joaquín García-Gómez

A5 josejgg@ual.es

A6 Antonio Escudero Gutierrez

A7 escudero@ua.es

A8 ${ }^{1}$ Universidad de Almería, Almería, Spain

A9 2 Departamento de Economía y Empresa, Área de Historia e Instituciones Económicas, Universidad

A10 de Almería, Ctra. Sacramento, s/n, 04120 Almería, Almería, Spain

A11 3 Universidad de Alicante, San Vicente del Raspeig, Spain

A12 4 Departamento de Análisis Económico Aplicado, Área de Historia e Instituciones Económicas,

A13 Universidad de Alicante, Ctra. San Vicente, s/n, 03690 San Vicente del Raspeig, Alicante, Spain 


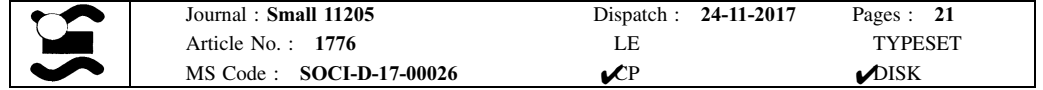

J. J. García-Gómez, A. Escudero Gutierrez

\section{Introduction: The Problem of Well-Being Measurement}

The majority of studies published before the 1980s used income per person or wages to estimate the standard of living. This point of view was based on the neoclassical economic theory that maintains that well-being is utility and, as this is subjective, should be measured in terms of monetary income as the recipients make choices in the market according to their tastes and preferences (Meier 1980; Stiglitz 1993). The use of monetary income as an indicator of the standard of living was first criticised in the 1970s and 1980s. The critics argued that income per person or wages are inputs of well-being, but they do not reflect the standard of living because they do not always capture some of its components such as life expectancy, education, working conditions, available leisure time, and costs of living in the city or environmental degradation. ${ }^{1}$

Amartya Sen's study was transcendental in this respect as it introduced a new conception of the standard of living. Monetary income is not well-being, but a means to obtain certain ends (to have health, to satisfy needs, to have choices, to have free time, to enjoy a long life). These are the ends that constitute the standard of living and to obtain them a series of access rights must exist (health, education, credit and liberty) (Sen 1993). At the end of the 1980s a group of economists, including Sen, designed the HDI based on these tenets. The HDI combines three elements, GDP per capita in constant dollars and adjusted for purchasing power parity, life expectancy at birth and educational attainment and is obtained through calculating the average of the three. ${ }^{2}$ The HDI may seem more reliable than income per capita because it includes other elements of well-being. However, it also has disadvantages. The first is that it conceals social inequality. The second is that it does not include important standard of living elements: working conditions, unemployment and the deterioration of the environment or the respect for human rights. The third drawback (common to all synthetic indicators) resides in the weighting. The HDI attributes a third part of well-being to income, another third to life expectancy and the remaining third to educational attainment. Why not assign $50 \%$ to income and $25 \%$ to each of the other two variables? Or, why not attribute $50 \%$ to life expectancy and $25 \%$ to the other two elements of well-being? Given the wide range of tastes and preferences, all weighting contains value judgements.

\footnotetext{
${ }^{1}$ We are referring to Norhdaus and Tobin (1973), Myrdal (1974), Samuelson (1983), or Morris (1979), who proposed alternative well-being indicators to income per person. The Nordhaus and Tobin's EWM (Economic Well-being Measure) and the Samuelson's NEW (Net Economic Well-being) modified the income adding variables like the value of leisure time and the housewives' work and deducting the military costs and the contamination and urban life costs. Morris proposed The Physical Quality of Life Index, which includes life expectancy at the age of 1 year, infant mortality and the adult literacy rate and is obtained through the arithmetic mean of its three parts. Morris has defended the viability of the indicator because it contains a function of well-being defined by the enjoyment of a long life with the possibility of prospering due to literacy and because, in under-developed countries, a substantial part of basic consumption is not made through the market, so infant mortality and life expectancy are better indicators than income for capturing nutrition and health. These variables are also easy to estimate and therefore are more reliable than the dubious figures for income of many under-developed countries.

${ }^{2}$ On the HDI, consult the Human Development Reports published from the year 2000 by the United Nations Development Programme. In 2010, the way to estimate the HDI was modified. The life expectancy was conserved as an indicator of health but the way to estimate education and the income changed, replacing the arithmetic average of the three components by a geometric one.
} 


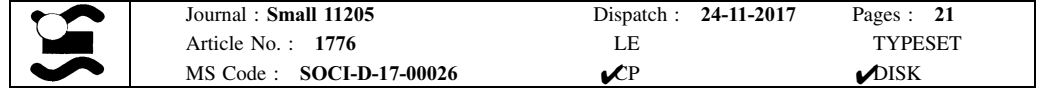

The Standard of Living of the Workers in a Spanish...

In the 1990s, average height became established as an indicator of the welfare. ${ }^{3}$ Anthropometric studies show that although there is a genetic load in height, this one is potential and it is altered by three factors that, along with genetics, determine the height that could be reached at age of 21 . We are talking about the nutrition, morbidity and physical wear because the height is the result of the "net nutritional input", which is the difference between "gross nutritional input" (ingested nutrients) and the energy spent through basal metabolism, physical activity and diseases. This makes the average height a biological measure of the standard of living, since the nutrition reflects the real wage and the consumption and the morbidity and the physical wear reflect some non-monetary elements of the standard of living as the epidemiological environment, the sanitary level and the labour conditions during childhood and adolescence.

Many studies published since the end of the 90's support that, due to the multidimensional nature of the well-being, there is no single indicator of well-being that reflects all of its components or does so without incurring value judgements. Therefore they advise that the evolution of the standard of living should be studied by comparing several indicators. ${ }^{4}$

The objective of this article is precisely to study the evolution of the well-being of the workers in Alcoy during the industrialisation process using four indicators: real wages, nutrition, life expectancy and average male height. Furthermore, we are analysing the effects of the public expenditures in the standard of living during the last decades of the nineteenth century and the first term of the twentieth.

The study is structured as follows. The first section is a short introduction explaining the history of the industrialization process in Alcoy. The second section presents the four indicators of well-being mentioned above. In the third section we will analyse the evolution of the standard of living between 1870 and the end of the nineteenth century. A "puzzle" emerged during this period, as two indicators pointed to an increase in well-being while the other two reveal the contrary. The fourth section studies the evolution of the standard of living between the beginning of the twentieth century and 1930. The "puzzle" disappeared during this period. Finally, the conclusions of the article maintain that the events in Alcoy coincide with the model recently proposed by Floud et al. (2011) regarding the evolution of the standard of living of the workers in British cities during the Industrial Revolution.

\section{The Industrialisation of Alcoy}

Alcoy (Fig. 1) is located in the interior and mountainous area of the province of Alicante. Its geographical location gave to the city the advantage of having hydraulic energy available of the Molinar river's falls of water and wool of the flocks of sheep that grazed in the valleys in winter and in summer in the mountains. This endowment of factors explains the development of a wool industry during the modern age, organized by the verlagssystem, which had its moment of glory in the eighteenth century. In the beginning of that

\footnotetext{
3 There is an abundant bibliography on anthropometry. Here we will only mention a few pioneering studies: Fogel and Engerman (1974), Engerman (1976), Eveleth and Tanner (1976), Fogel et al. (1982), Fogel (1989), Tanner (1990), Steckel (1995), Steckel and Floud (1997), Komlos and Baten (1998) and the recent compilation of studies edited by Floud et al. (2014). For Spain, see Martínez-Carrión and Puche (2011).

4 Pioneer studies which defend the use of several indicators of well-being include Crafts (1997), Floud and Harris (1997) and Horlings and Smits (1998). More recently, Stiglitz et al. (2010). For the Spanish case, Escudero and Simón (2003) have studied the evolution of well-being between 1850 and 1992 using income per person, the Physical Quality of Life Index, the Human Development Index and height.
} 


\begin{tabular}{|l|lcc|}
\hline & Journal : Small 11205 & Dispatch : 24-11-2017 & Pages : 21 \\
Article No. : 1776 & LE & TYPESET \\
MS Code : SOCI-D-17-00026 & CP & DISK \\
\hline
\end{tabular}

J. J. García-Gómez, A. Escudero Gutierrez

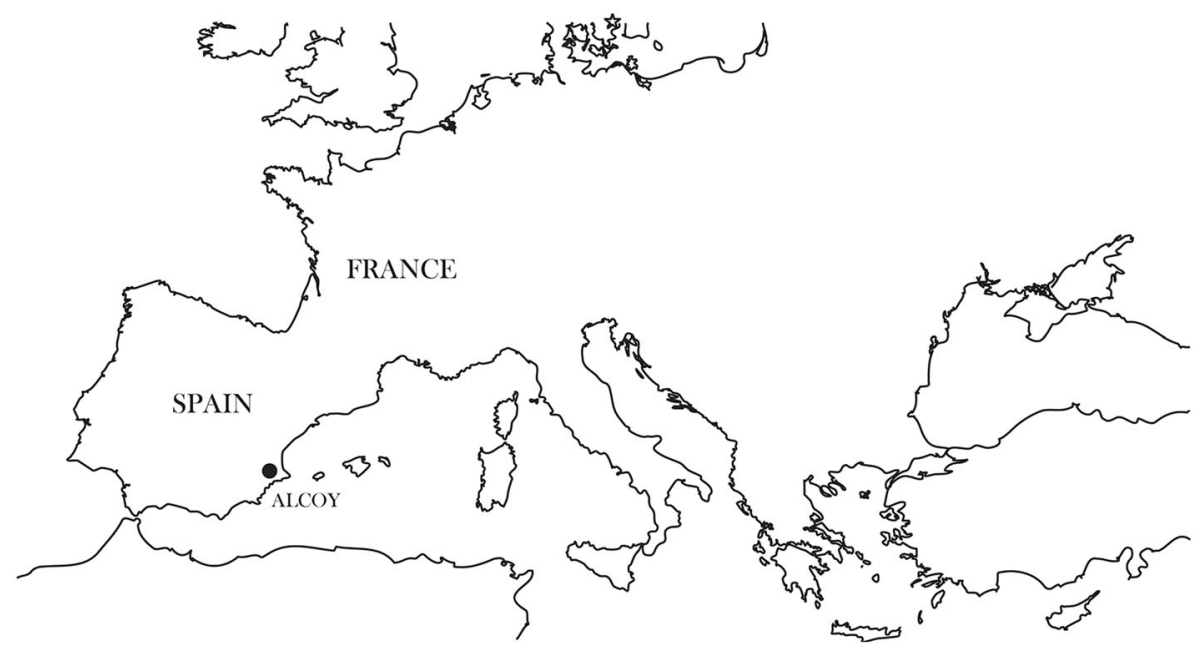

Fig. 1 Alcoy

century, Felipe V's New Plant Decrees after the War of Succession ${ }^{5}$ unified the Spanish market, so alcoyan drapes could be sold in Castile and in the American colonies without yielding custom duties. Spinning and wool carding in peasant households located out of town went together with the beating, weaving and dying held in Alcoy by craftsmen organized in guilds.

These protoindustries began to be inefficient at the end of the 18th due to the high transaction costs, reason why some traders began to concentrate production in factories with hydraulic machinery. ${ }^{6}$

The existence of entrepreneurs, trained workforce and hydropower, as well as the progressive mechanization of spinning and weaving factories made Alcoy in the midnineteenth century the second Spanish wool producer centre after Sabadell and Terrassa, cities located in the province of Barcelona. ${ }^{7}$ Alcoy was specialized in wool of lower price and quality than the Catalan, and its trade was focused in the Spanish market, protected with high customs duties. At the same time, and thanks to hydropower and the wide range of drapes, a paper industry was developed in the city, becoming in 1856 the second largest producer of Spain after Barcelona. The third industrial sector in Alcoy during this period was the mechanical industry needed to repair and build machinery. ${ }^{8}$

\footnotetext{
5 The war of succession to the Spanish Crown was originated after the death of Carlos II in 1701. France and the Kingdom of Castile defended Felipe of Anjou, of the dynasty of the Bourbons. The Kingdom of Aragon and the Great Coalition (England, United provinces, Austria and Prussia) defended the Archduke Charles, of the dynasty of the Habsburgs. Once Philip of Anjou was named King of Spain, signed the Nueva Planta Decrees, which abolished the ancient privileges of the Crown of Aragon in 1707.

${ }^{6}$ On the wool industry in Alcoy since the 14th c. to the 18 c., see Torró Gil (1994a, b, 2004).

7 Since we do not have data the Spanish production of wool in the nineteenth century, specialists have used tax data for the main production centres. Data suggest that in 1856, 30\% of Spanish wool production came from Terrassa and Sabadell, and $10 \%$ of Alcoy. Nadal (2003, p. 141).

${ }^{8}$ General studies on the industrialisation of Alcoy are Aracil and García (1974), Cerdá (1967, 1980) and Cuevas (1999). On the paper industry, see Gutierrez (2011) and Nadal (2003, pp. 154, 179).
} 


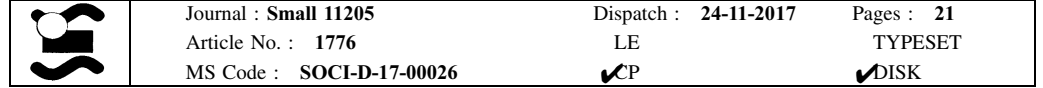

The Standard of Living of the Workers in a Spanish...

Alcoyan textile industry experienced since the end of the nineteenth century a new thrust thanks to the arrival of the railroad to the city and to the replacement of the hydraulic energy by steam engines, elements that impacted favourably in the engineering mechanical industry. In 1931, Alcoy remained the second Spanish wool producer centre. Also since the end of the nineteenth, its paper industry became mechanized and specialized in the manufacturing of cigarette's paper, which was sold on the Spanish market and in Cuba and South America, being one of the few Spanish exporting companies. ${ }^{9}$

The industrialization of Alcoy provoked a strong demographic growth which is discussed in the next section, and originated a structure of workforce with a strong component of industrial workers. ${ }^{10} \mathrm{We}$ are, therefore, studying a typical town of the first Industrial Revolution.

\section{Four Indicators of the Standard of Living of the Workers in Alcoy: Real Wages, Nutrition, Life Expectancy and Height (1870-1930)}

The construction of a rigorous series of real wages requires nominal wage data drawn from reliable sources and a cost-of-living index that contemplates: (1) retail prices in the area under consideration of the goods and services consumed by the workers; (2) the relative importance of each of these goods and services in consumption and (3) the variations in demand derived from Engel's law. ${ }^{11}$

Figure 2 shows the aggregate nominal wages of the workers in Alcoy between 1870 and 1930. The wages are drawn from primary sources which are specified under the Fig. 2. In order to aggregate the series, we have included those professions for which we have wage data for all of the years: rural day labourer, bricklayer, unskilled urban workman, weaver, dyer, spinner, carder and shop assistant. We have finally applied an arithmetic and nonweighted measure as we do not have sufficient information regarding the number of workers of each profession.

Figure 3 shows the cost-of-living index with which we have converted the nominal wages into real wages. The prices are retail prices and have been taken from mercurial books, account books of the hospital of Alcoy and housing rental records. The goods and services consumed by the working class and their weighting can be seen in Table 1.

The evolution of the cost-of-living index is highly similar to the one constructed by Jordi Maluquer for Spain and which is also shown in Fig. 3: modest growth of prices between 1850 and 1913; inflation during the First World War and the post-war period and a subsequent decline (Maluquer 2006). There is, however, a small difference. In the case of Alcoy, the CPI ${ }^{12}$ increased more between 1896 and 1913 because the good economic

\footnotetext{
${ }^{9}$ Gutiérrez (2011, op. cit.).

${ }^{10}$ In $1860,60 \%$ of the active population worked in the industry and this percentage came to exceed $75 \%$ in the Decade of 1920. The data have been calculated by José Joaquín García making use of the municipal censuses of population and the municipal statistics of labourers.

${ }^{11}$ Engel stated that the percentage of income allocated for food purchases decreases as income rises. Economists have extended this definition considering that as a household's income increases, the percentage of income spent on inferior goods decreases while the proportion spent on other goods (such as luxury goods) increases. One of the issues discussed in the debate on the standard of living of the British working class during the Industrial Revolution relates to the conditions that the estimate of real wages should fulfil. See, for example, Flinn (1974), Lindert and Williamson (1983), Crafts (1985), Scholliers (1989), Feinstein (1998) and Clark (2001).

${ }^{12}$ The CPI measures the changes in the price of a market basket of consumer goods and services representing the consumption of the households.
} 


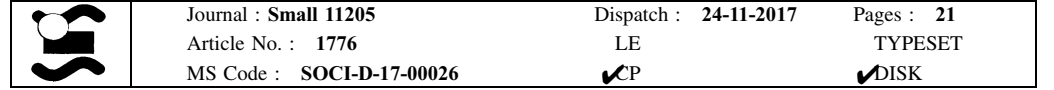

J. J. García-Gómez, A. Escudero Gutierrez

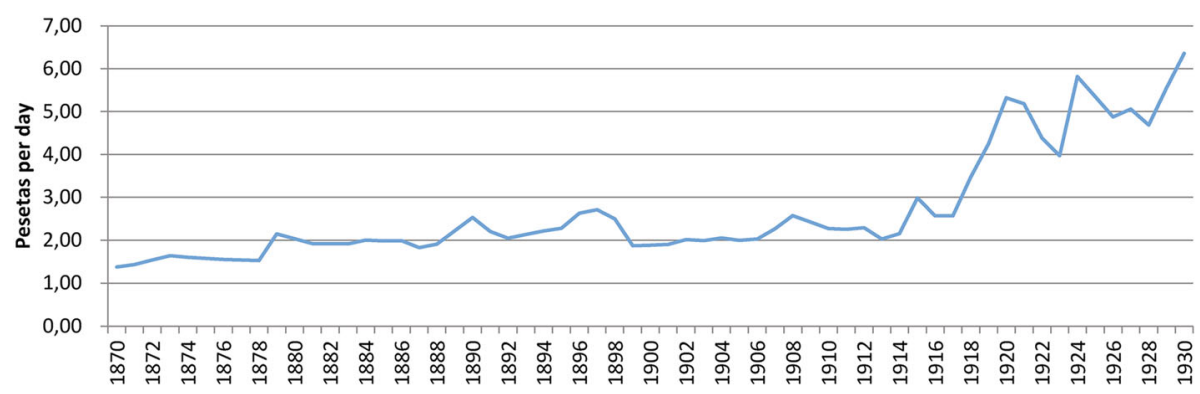

Fig. 2 Nominal wages in Alcoy (1870-1930). Nominal pesetas Source: The nominal wages have been obtained from the documentation in the following four archives: the Archivo Municipal de Alcoy, the Archivo de la Diputación Provincial de Alicante, the Archivo de la Real Fábrica de Paños de Alcoy (ARFPA) and the Archivo Histórico del Instituto Nacional de Estadística. The total number of observations was 12,300 wages which provides the sample with sufficient significance. Until 1881, data come from the records of ARFPA, the Hospital's account books and budget settlements of the City Hall, completed with the occasional available statistics and historical press. Between 1881 and 1930 data come mainly from "Census Books of personal identification cards" and from labor agreements that were signed in the city since 1881

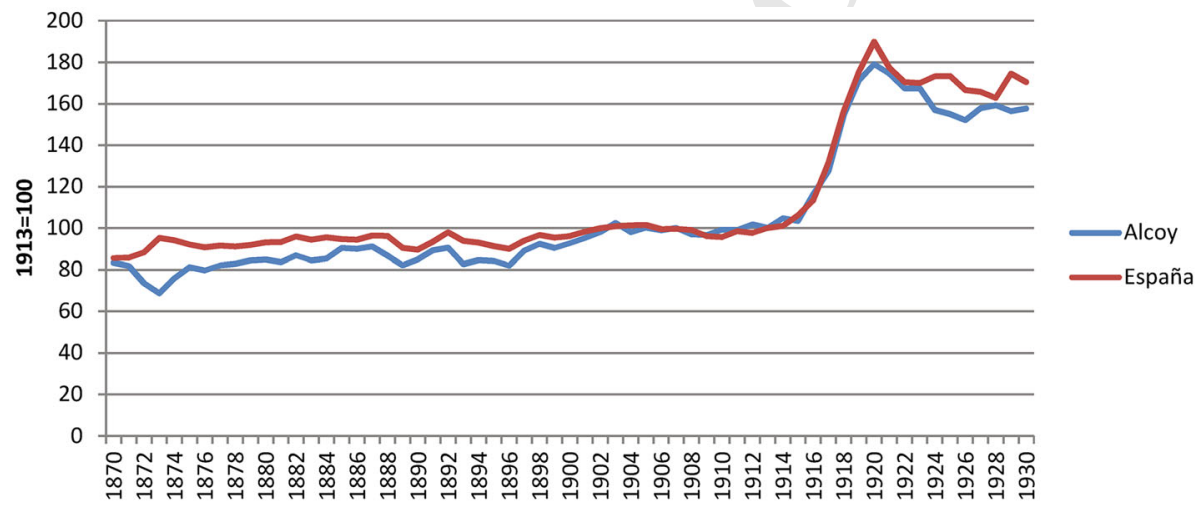

Fig. 3 CPI in Alcoy and Spain (1870-1930). $1913=100$ Source: The mercurial books have been consulted in the Archivo Municipal de Alcoy, in the Archivo de la Diputación de Alicante and in the Archivo Histórico del Instituto Nacional de Estadística. The accounts books of the hospital and the housing rental records can be found in the Archivo Municipal de Alcoy. In total, we have obtained 36,000 references of goods and services. See text

139 climate experienced by industry in the town gave rise to an increase in immigration which 140 increased the price of some foods and services. The composition of spending of working 141 class families in Table 1 is similar to that which other authors have created for Spain and 142 other regions. It is also similar to the composition of spending prevailing in Great Britain 143 during the Industrial Revolution: between 1871 and 1918, 69\% of spending corresponded 144 to food. This percentage decreased to $65 \%$ between 1919 and the 1930 s, therefore fulfilling 145 Engel's law. ${ }^{13}$

13 Cost-of living indices of the Spanish regions are those of Moreno Lázaro (2006) for Castilla la Vieja; Lana Berasaín (2005) for Navarre; Molina de Dios (2003) for Mallorca and Pérez Castroviejo (2006) for Biscay. CPIs for the Great Britain of the Industrial Revolution in Feinstein (1998) and Clark (2001). 


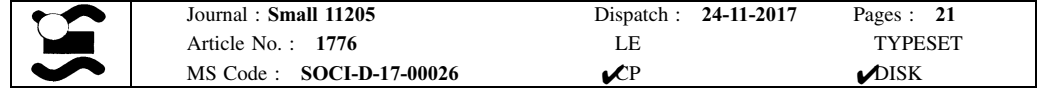

The Standard of Living of the Workers in a Spanish...

Table 1 Structure of spending of working class families in Alcoy (1871-1936) Source: The shopping basket for the period 18711918 has been taken from a family budget given by the Institute of Social Reforms. Those corresponding to the periods 1919-1926 and 1927-1930

have been constructed with information drawn from the purchases made by the town's hospital and reflected in the afore-mentioned accounts books

\begin{tabular}{|c|c|c|c|}
\hline & 1871-1918 & 1919-1926 & 1927-1936 \\
\hline FOOD & 69.88 & 68.90 & 65.77 \\
\hline Bread & 21.56 & 16.60 & 15.93 \\
\hline Lamb & 8.67 & 0.40 & 2.12 \\
\hline Pork & 8.67 & 0.05 & 2.98 \\
\hline Veal & 0.00 & 23.04 & 17.53 \\
\hline Wine and spirits & 10.15 & 2.48 & 5.85 \\
\hline Oil & 1.43 & 1.57 & 0.61 \\
\hline Legumes & 2.72 & 2.41 & 4.02 \\
\hline Rice & 2.68 & 5.44 & 2.90 \\
\hline Potatoes & 0.00 & 2.46 & 1.53 \\
\hline Sugar and chocolate & 4.33 & 3.78 & 4.64 \\
\hline Fresh fish & 0.00 & 0.00 & 1.06 \\
\hline Salted products & 6.64 & 0.22 & 0.28 \\
\hline Milk & 0.00 & 1.42 & 0.28 \\
\hline Fruit and vegetables & 1.45 & 0.17 & 0.42 \\
\hline Salt & 1.08 & 0.87 & 1.12 \\
\hline Eggs & 0.50 & 7.98 & 4.48 \\
\hline Housing & 10.71 & 10.71 & 10.71 \\
\hline Clothing & 7.14 & 6.34 & 8.55 \\
\hline Cleaning and hygiene & 1.56 & 4.91 & 3.36 \\
\hline Heat and electricity & 10.71 & 9.14 & 11.61 \\
\hline
\end{tabular}

Nominal wages and the cost-of-living index have been used to estimate the first indicator of the standard of living of the workers of Alcoy: their real wages (Fig. 4).

A second indicator of the standard of living is nutrition. Table 2 shows the calories per person and day for five representative diets of the workers of Alcoy between 1868 and 1928. The food and drinks consumed and their quantity have been estimated using diet records and also the apparent consumption method. More specifically, the diets of 1868 and 1928 have been calculated using the diet records obtained from the municipal hospital and those of 1884, 1897 and 1912 have been drawn from records of the town's food imports, enabling us to estimate the apparent consumption. ${ }^{14}$ Knowing the amounts of each product, we have calculated the calories through the Spanish Food Composition Database.

Table 2 shows that until the mid-1880s, the diet was monotonous and mainly based on vegetable products. Between 1884 and 1910, the diet continued to be vegetable-based, but 158 with a wider range of products and a greater presence of animal products (meat, fish, eggs and milk) as well as sugar, which means that the nutrition transition began in the $1880 \mathrm{~s} .{ }^{15}$

\footnotetext{
14 The apparent consumption is a method widely used in Economy and Economic History to estimate the consumption of a country or a region. It is defined as the production plus imports minus exports, sometimes also adjusted for changes in inventories.

15 We use the term "nutrition transition" in the sense proposed by Popkin (1993). An initial period before the Neolithic period which Popkin called "food collection" was followed by the "hunger" stage. At the end of the eighteenth century, another phase began characterised by diets based on saturated fats, sugar and carbohydrates which, well into the twentieth century gave rise to an increase in obesity. We should point out that the nutrition transition did not occur in the same way in Atlantic Europe as it did in Mediterranean Europe as in the latter case it began later and was a slower process. See Pujol and Cussó (2014).
} 


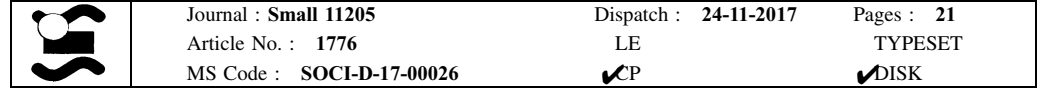

J. J. García-Gómez, A. Escudero Gutierrez

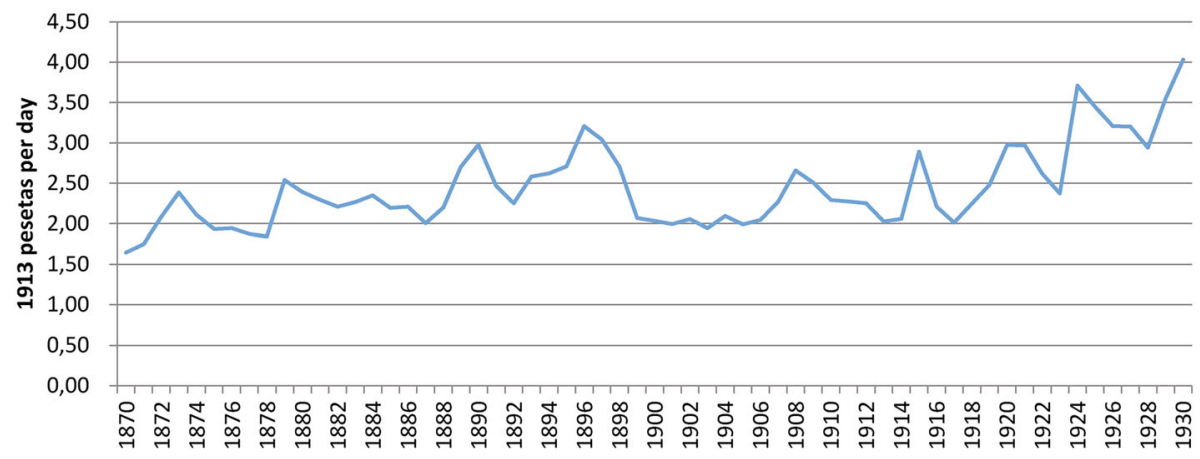

Fig. 4 Real wages in Alcoy (1870-1930). Own elaboration. Real wages in constant 1913 pesetas. To take into account the changes in the preferences of the consumers, reflected in the evolution of the composition of consumption baskets, we have calculated an index of Laspeyres using each shopping basket in the corresponding sub period

160 During the 1920s, the full Mediterranean diet became commonplace. It constituted a diet 161 with more vegetable products that that of Atlantic Europe which was complemented with 162 meat and eggs and with a high consumption of fish and milk.

A third indicator of well-being is life expectancy. We have calculated this by constructing mortality tables with information drawn from the sources listed in the foot of the Table 3. The methodology used in the calculation of the mortality tables is based in the actuarial method, widely accepted (Deaton 2013) and explained in depth, for example, in Vazquez et al. (2003). The results can be found in the next table.

The fourth and final indicator of the standard of living which we are going to use is the average male height. In this case, the data have been provided by our colleague Javier Puche Gil, whom we thank for providing us with the average height of soldiers measured in Alcoy which can be seen in Fig. 5. We should point out that the graph only shows the height of the recruits born in Alcoy, therefore avoiding any bias caused by including young immigrants born in rural areas with lower heights. We should also note that the $\mathrm{x}$-axis shows the years of birth of the recruits.

\section{The Standard of Living of the Workers in Alcoy (1870-End of the Nineteenth Century)}

177 Between 1870 and 1898, the nominal wages (Fig. 2) grew at an accumulative annual rate of $1782.2 \%$ due to the increase in the demand for labour which occurred during this period. ${ }^{16}$ 179 However, wages fell in the last 2 years of the nineteenth century as this was when an 180 adjustment began which had been triggered by the strong influx of immigrants into the 181 town. This growth of $2.2 \%$ falls to $1.78 \%$ when the nominal wages are converted into real 182 wages (Fig. 4). So, if we use real wages as an indicator of the standard of living during the 183 last third of the nineteenth century, we will reach the conclusion that this improved slightly 184 as the workers in Alcoy were able to buy a higher amount of goods and services. The same

\footnotetext{
16 This can be clearly seen between the end of the 1860s and the 1890 s when the population of Alcoy increased by $30 \%$.
} 


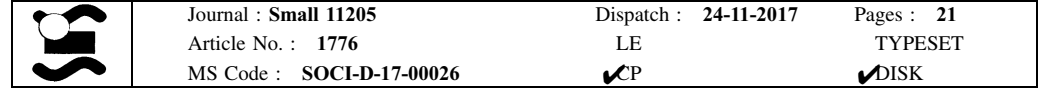

The Standard of Living of the Workers in a Spanish...

Table 2 calories per person and day of the working man's diet in Alcoy (1868-1928) Source: In the Archivo Municipal de Alcoy we can find the monthly summaries of the introduction of food products into the town. This data was drawn from Beneito (2003) and with it we have estimated the diet of the years 1884, 1897 and 1912 through the apparent consumption method. The diets of 1868 and 1928 have been drawn from the diet records of the town's hospital and can be found in the Archivo Municipal de Alcoy

\begin{tabular}{|c|c|c|c|c|c|}
\hline Food & 1868 & 1884 & 1897 & 1912 & 1928 \\
\hline Wine (red) & 79.39 & 126.46 & 110.06 & 85.01 & 116.38 \\
\hline Oil (olive) & 286.50 & 490.78 & 224.68 & 321.27 & 128.26 \\
\hline Fish (sardine) & & 11.57 & 37.44 & 18.95 & 2.32 \\
\hline Salted products (cod, salted, raw) & 33.82 & 25.40 & 20.12 & 13.14 & 8.32 \\
\hline Horse meat & 0.00 & 14.27 & & & \\
\hline Pork (unspecified cut) & 122.89 & 54.40 & 89.38 & 58.13 & 92.21 \\
\hline Beef (veal, unspecified part, raw) & 0.00 & 2.81 & 4.85 & & 5.02 \\
\hline Lamb (unspecified part) & 159.94 & & 99.47 & 75.65 & 102.62 \\
\hline Charcuterie (sausages) & & 4.64 & 5.22 & 6.06 & 7.16 \\
\hline Rice/chick peas (average of the two) & 430.77 & 176.23 & 231.51 & 149.60 & 63.58 \\
\hline Bread (white wheat) & 815.88 & 1249.32 & 1349.26 & 1496.69 & 1671.74 \\
\hline Eggs (hens, fresh) & 3.06 & 0.00 & 81.71 & 57.21 & 70.51 \\
\hline Milk (cow's, full fat) & 32.19 & 8.00 & 4.47 & 1.95 & 1.45 \\
\hline Vegetables (green beans, raw) & & & & 0.04 & 4.62 \\
\hline Hen (whole, raw) & 2.32 & 8.18 & 5.00 & 7.69 & 14.06 \\
\hline Sugar (white) & 62.14 & 55.16 & 50.06 & 106.65 & 238.72 \\
\hline \multicolumn{6}{|l|}{ Salt } \\
\hline Vinegar (wine) & 0.42 & 0.42 & 0.42 & & \\
\hline Potatoes (raw) & 17.29 & 17.28 & 17.28 & 25.60 & 38.90 \\
\hline Chocolate (dark, with sugar) & & & & & 2.66 \\
\hline Soup (consommé) (vegetable broth) & & & & & 262.50 \\
\hline Total (Kcal) & 46.61 & 2244.90 & 2330.94 & 2423.62 & 2831.05 \\
\hline
\end{tabular}

Table 3 Life expectancy in Alcoy (1877-1930)

\begin{tabular}{llr}
\hline Years & Men & Women \\
\hline 1877 & 33.07 & 36.70 \\
1900 & 32.06 & 35.90 \\
1910 & 35.07 & 38.13 \\
1920 & 35.40 & 40.36 \\
1930 & 43.78 & 49.10 \\
\hline
\end{tabular}

Own elaboration using several sources. The number of people counted in each year classified by age groups is drawn from the Population Census of the town of Alcoy. The number of deaths by age and the number of births of 1877, 1900 and 1930 have been obtained of the doctoral thesis of Beneito (1993). For the years 1910 and 1920 have been used the deaths of the Registro Civil 


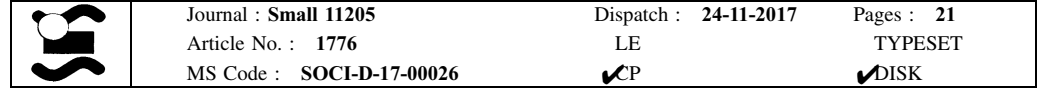

J. J. García-Gómez, A. Escudero Gutierrez

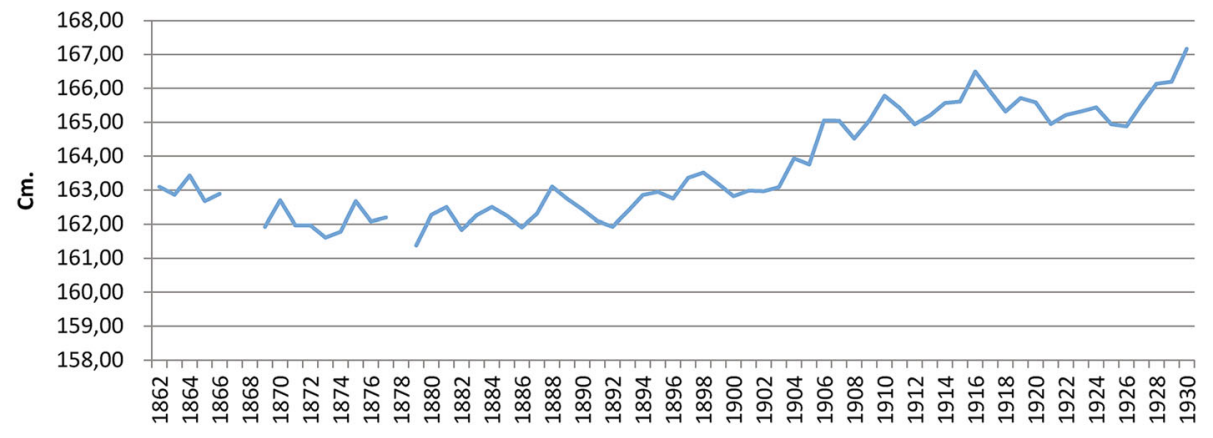

Fig. 5 Height of the conscripts born in Alcoy (1870-1930). Source: Puche Gil (2009). From his excellent work on Alcoy (including 16.102 data of recruits between 19 and 21 years measured from 1876 to 1936) we have selected only the series of conscripts born in the city, and all the data are standardised at age 21

185 result is generated by the nutrition indicator as energy consumption between 1868 and 1897 rose from 2046 to 2330 kilocalories, as we can see in Table 2.

If we compare the first two indicators of well-being with the third, we observe that the life expectancy fell between 1877 and 1900 (Table 3). The explanation for this phenomenon resides in the fact that Alcoy experienced an urban penalty, a term used by historians and demographers to define the higher death rate in urban areas during the Industrial Revolution. ${ }^{17}$ We believe that this phenomenon could be analysed using Economic Theory and, more specifically, that relating to market failures. First we will present our hypothesis and subsequently attempt to ratify it in the case of Alcoy.

In any Economics manual we will find a chapter which talks about the virtues of the market using the metaphor of the invisible hand to explain how the State should intervene when there are problems that the market cannot resolve satisfactorily. There are many of these problems or failures: imperfect information, public goods, merit goods, negative externalities, monopolies and periodical crises together with high rates of unemployment (Stiglitz 1993, pp. 195; Krugman et al. 2007, pp. 258). Our hypothesis is that the urban penalty was a consequence of four of these market failures. The first is concerned with the provision of public goods. These are goods which private companies have no incentive to provide, since they are non-excludable and non-rival: nobody can be excluded from their free use and use by one individual does not reduce availability to others. The paradigmatic example is a lighthouse. Although a lighthouse is necessary, no private business will construct one because it cannot exclude free riders from using it. A second is that of providing merit goods. Merit goods are those such as housing, healthcare and education, which are considered necessary for a satisfactory standard of living and which the market does not produce optimally, either because it provides them too slowly or because the amount supplied is insufficient. The State should intervene in the provision of these socalled merit goods because in this way it will increase overall well-being. The third type of 211 failure refers to those derived from imperfect information. An example is food products, as 212 the consumer often cannot know whether they have been adulterated or are in poor

\footnotetext{
17 On the urban penalty, Preston and Van de Walle (1978), Woods and Woodward (1984), Woodward (1984), Kearns (1988, 1991), Bairoch (1988), Schofield et al. (1991), Mooney (1994), Vögele (1998, 2000), Szreter and Mooney (1998), Woods (2000, 2003), Haines (2001, 2004). A statement of the situation in Spanish is to be found in Escudero and Nicolau (2014).
} 


\begin{tabular}{|l|lcc|}
\hline & Journal : Small 11205 & Dispatch : 24-11-2017 & Pages : $\mathbf{2 1}$ \\
Article No. : 1776 & LE & TYPESET \\
MS Code : SOCI-D-17-00026 & CP & DISK \\
\hline
\end{tabular}

The Standard of Living of the Workers in a Spanish...

condition. Finally, there is the issue of negative externalities, referring to the negative consequences that the action of an economic agent has on the well-being of a third party. An example would be the installation of a chemical company that contaminates a river, thus preventing any fishing activity.

In our opinion, the urban penalty was the result of an environmental deterioration which increased the risk of contracting infectious diseases transmitted through water, food and air. Let us see why this increased mortality was related to market failures derived from an anarchic urbanisation:

\subsection{Contaminated Water}

Basically, this was due to the absence of sewage facilities. Given that homes were not connected to a sewage system by pipes and waste water was evacuated in buckets into the drains of the street, this constitutes a public good. Private companies did not undertake the construction of a sewage system because nobody could be excluded from its free use. Paul Krugman uses this as an example of a public good in his Economics manual, referring to how the municipal authorities were obliged to construct the modern sewage system of London after the Great Stink of 1858 (Krugman et al. 2007, pp. 258-259).

\subsection{Spoiled Food}

A market failure due to imperfect information. Incorrect handling, deficient hygiene standards of warehouses and shops and adulteration gave rise to the sale of spoiled food unknown to the consumers. This was likely to be more serious among the working class as the upper and middle classes would have had access to more 'reputable' stores which mitigated the imperfect information problem.

\subsection{Polluted Air}

This negative externality was also more severe in the working class neighbourhoods and was due to two causes. The first is related to the slowness of the market to provide a merit good such as housing and the second to the freedom of urbanising and construction without any types of regulations. The bibliography on construction economics shows that the supply of housing is inelastic in the short term. ${ }^{18}$ In addition to this market failure, the demand for housing "shot up" in the working class neighbourhoods as a consequence of an avalanche of immigrants. Therefore, rent prices also increased which obliged families to sublet rooms to other people which generated overcrowding and polluted air. Another contributing factor was that the building of narrow streets, tall buildings and small flats was permitted which prevented adequate ventilation.

The only efficient way of correcting market failures such as those that caused the urban penalty is State intervention. This can be seen in the success of the sanitary reform measures proposed by the hygienists: sewage system, quality control of food, construction

\footnotetext{
18 The construction of housing requires a series of previous conditions which extend the execution time of the works (the project design, purchase of the land, construction license, bank loans, hiring of the construction company and the time of execution was rarely less than 2 years). Although there are many studies that explain why adjustments in the real estate markets do not take place in the short term, we can highlight Smith et al. (1988).
} 


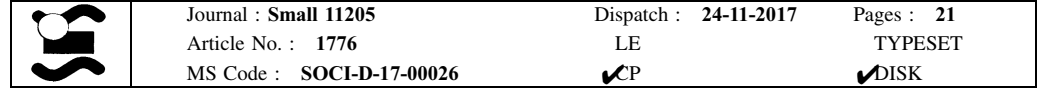

J. J. García-Gómez, A. Escudero Gutierrez

Table 4 Percentage of deaths from infectious diseases in Alcoy and the adjacent agricultural area (18751900) Source: Beneito (1993)

\begin{tabular}{lll}
\hline Period & Alcoy $(\%)$ & Adjacent agricultural area $(\%)$ \\
\hline $1875-1879$ & 52.80 & 45.00 \\
$1898-1900$ & 60.00 & 47.50 \\
\hline
\end{tabular}

of cheap housing which tempered overcrowding and the hygienic regulation of urban development and housing construction. ${ }^{19}$

We will now examine the data that confirm that Alcoy suffered from an urban penalty. During the last third of the nineteenth century, the population density of the town was very high with an average of 90,000 inhabitants per $\mathrm{km}^{2}$ and 250,000 inhabitants per $\mathrm{km}^{2}$ in some working class neighbourhoods (Dávila 1993). This was due to two facts. The population increased by $30 \%$ as a result of immigration and Alcoy had serious problems in terms of its urban growth due to its location in a valley between several mountain ranges which is crossed by three rivers. Therefore, in addition to a high population density there was a high compactness (the ratio between the built-up area and the open space) (Dávila 1993, op. cit.). If we also add the absence of sewage facilities and the quality control of food and the overcrowding of homes, it follows that the incidence of infectious diseases transmitted through the air, water and contaminated foods would have risen. This can be seen in Table 4, which shows the percentages of mortality caused by infectious diseases in Alcoy and in the adjacent agricultural area during the last third of the nineteenth century. We can observe that the percentages were higher in Alcoy than in the rural area and that the incidence of these diseases in the town rose from 52 to $60 \%$, which explains the reduction in life expectancy. In the same respect, the air-borne diseases represented 39\% of mortality rates and those transmitted by water and contaminated food represented $15 \%$. The remaining $6 \%$ of mortality was due to infections caused by other vectors (Beneito 1993). Moreover, it is plausible, although data are not available, that between 1880 and 1897 the percentage of deaths caused by infectious diseases in the total overtook the $60 \%$ of the last years of the nineteenth, because we can see in the Table 5 that the mortality rate was $34.5 \%$ in $1887 .{ }^{20}$ This phenomenon suggests that the city began to suffer the urban penalty (higher mortality rates and lower life expectancy than in the hinterland) in the 1860 and 1870 decades but the hardest situation was lived in the 1880 and the first 1890, and it did not begin to be mitigated until the implementation of the sanitary reform, since 18931894 (see Table 6). This would explain that the mortality rate in 1900 was similar than in 1877 and the percentage of mortality caused by infectious diseases in the total was slightly higher in 1900 than in 1877.

Another fact which reveals the existence of an urban penalty in Alcoy is the contrast between the crude mortality rates in the town, those of Spain and those of rural Spain. Although for comparison purposes these rates are affected by the population structure, we believe that the results shown in Table 5 are significant. In 1878, Alcoy had a similar rate to the Spanish average. In 1887, this rate increased, surpassing the rate for Spain and the

\footnotetext{
${ }^{19}$ Other measures proposed by the hygienists were the paving of the streets, refuse collection, vaccination, the "Gotas de Leche" child nutrition programme and the outreach campaigns about child care and child nutrition and personal and domestic hygiene. On health reform in the cities, see Szreter (2002a, b, c, 2005). Also Bell and Millward (1998), Fraser (1993), Luckin (2000), Harris (2004) and Sheard and Power (2000). ${ }^{20}$ In fact, in other Spanish city suffering urban penalty as La Unión, this percentage reached to $86.4 \%$ between 1877 and 1900. (Escudero, García-Gómez and Martínez Soto, work in reviewing).
} 


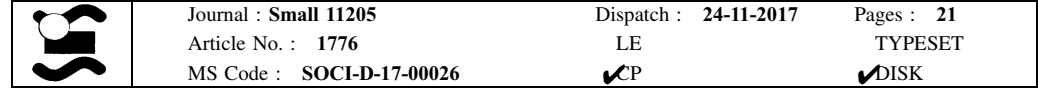

The Standard of Living of the Workers in a Spanish...

Table 5 Crude mortality rates in Alcoy, Spain and Rural Spain (1878-1900) Sources: Alcoy, Beneito (2003). Spain, Nicolau (2005). Rural Spain, Reher (1990)

\begin{tabular}{llll}
\hline Years & Alcoy & Spain & Rural Spain \\
\hline 1878 & 30.20 & 30.40 & n/a \\
1887 & 34.90 & 32.70 & 30.20 \\
1897 & 30.32 & 28.30 & 27.9 \\
1900 & 29.30 & 28.80 & $\mathrm{n} / \mathrm{a}$ \\
\hline
\end{tabular}

Table 6 Public expenditure on the sanitary reform of Alcoy (1866-1914) Source: See text

\begin{tabular}{lll}
\hline Five year period & (1) Spending on sanitary reform & (2) Spending on sanitary reform per capita \\
\hline $1866-1870$ & $42,368.51$ & 1.50 \\
$1871-1875$ & $53,731.57$ & 1.75 \\
$1876-1880$ & $57,254.43$ & 1.78 \\
$1881-1885$ & $43,865.97$ & 1.41 \\
$1886-1890$ & $41,952.68$ & 1.39 \\
$1891-1895$ & $102,464.71$ & 3.33 \\
$1896-1900$ & $127,105.87$ & 4.05 \\
$1901-1905$ & $116,564.85$ & 3.57 \\
$1906-1910$ & $233,768.63$ & 6.97 \\
$1911-1914$ & $390,918.44$ & 11.33 \\
\hline
\end{tabular}

Constant pesetas of 1913

rate of rural Spain. Although at the end of the nineteenth century the rate of Alcoy had fallen, it was still higher than the other two rates.

If we now use height as an indicator of the standard of living (Fig. 5), we can observe that it also reveals a decrease in well-being during the last third of the nineteenth century as the average height of those born in 1862 was 163 centimetres which evolved roughly constant in the period between this year and 1898. As we already know, height at the age of 20-21 years of age is the result of the net nutritional input, the difference between the crude nutritional input (the nutrients consumed) and the energy expended through basal metabolism, physical activity and illnesses. The stagnation in height in Alcoy had three causes: a) despite the increase in food consumption the diet was still not sufficient to cover the energy needs required by physically demanding jobs; b) there was a high incidence of child and adolescent labour with harsh working conditions ${ }^{21}$ and c) the deterioration of the urban environment gave rise to higher morbidity rates.

All of this indicates that the standard of living of the workers in Alcoy diminished during the last third of the nineteenth century as the slight increase in real wages and consumption masks the deterioration in sanitary and working conditions reflected in morbidity, life expectancy and height.

${ }^{21}$ For child labour and the harsh working conditions in Alcoy during the industrialisation process, see Beneito (2003). 


\begin{tabular}{|l|lcc|}
\hline & Journal : Small 11205 & Dispatch : 24-11-2017 & Pages : 21 \\
Article No. : 1776 & LE & TYPESET \\
MS Code : SOCI-D-17-00026 & CP & DISK \\
\hline
\end{tabular}

J. J. García-Gómez, A. Escudero Gutierrez

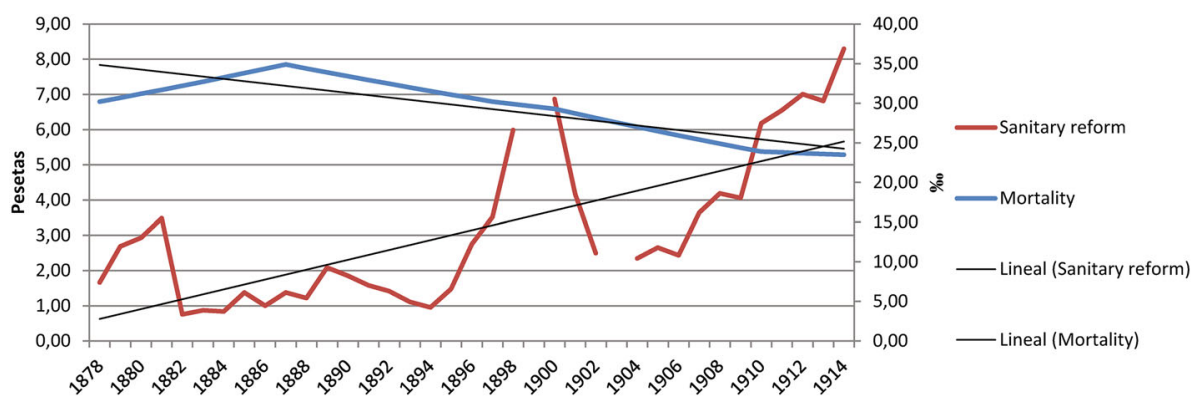

Fig. 6 Crude mortality rate and expenditures in the sanitary reform in Alcoy (1878-1914). Own elaboration. Sanitary reform expenditures per capita in real 1913 pesetas with a gap of 5 years. Crude mortality rates in \%o Sources: Budgets of the local government of Alcoy from 1865 to 1911 (sanitary reform) and «Estadística de movimiento natural de la población entre 1843 y 1860» (Archivo Municipal de Alcoy), Register of deaths in Alcoy (Civil register of Alcoy) and Beneito (2003)

\section{The Standard of Living of Workers in Alcoy (Begining of the Twentieth Century-1930)}

Figure 2 shows that between 1901 and 1930, nominal wages grew substantially with an accumulative annual average rate of $4.23 \%$. We should point out however, that between 1901 and 1913, wages remained virtually unchanged as a result of the afore-mentioned adjustment in the labour market. The nominal wage grew strongly during the First World War and the 1920s. The inflationist gap generated by the conflict and the strike movements forced entrepreneurs to increase wages which subsequently continued to rise due to the positive situation that the town's industry experienced during the Dictatorship of General Primo Rivera and to the emergence of a labour market with collective bargaining. ${ }^{22}$

Between 1901 and 1930, real wages (Fig. 4) also increased, although at a lower accumulative average rate than nominal wages (2.7\% as opposed to $4.23 \%)$. However, between 1901 and 1913 real wages remained practically stable; they increased in 1914 and 1915 despite the increase in the CPI; they fell temporarily in 1916 and 1917 as a consequence of the higher inflation and, although they later experienced variations, they displayed a clearly upward trend until 1930 . Therefore, if we use real wages as an indicator of well-being, we will reach the conclusion that well-being increased between the beginning of the twentieth century and 1930 .

The second indicator of the standard of living which we have used indicates the same trend. As we can observe in Table 2, in 1897 calories consumption was 2330; in 1912 it was 2423 and in 1928 it was 2831. The evolution of life expectancy also indicates an increase in well-being because in 1900 it was 32.06 years for men and 35.90 years for women and in 1930 it had increased to 43.78 and 49.10 years respectively (Table 3). The better nutrition undoubtedly contributed to the decrease in mortality but the information that we will examine below shows that a crucial factor in the progressive disappearance of the urban penalty was the sanitary reform which the local government of Alcoy implemented at the end of the nineteenth century.

22 A more in-depth analysis of the evolution of nominal and real wages can be found in García-Gómez (2013), pp. 503-536. 


\begin{tabular}{|l|lcc|}
\hline & Journal : Small 11205 & Dispatch : 24-11-2017 & Pages : 21 \\
Article No. : 1776 & LE & TYPESET \\
MS Code : SOCI-D-17-00026 & CP & DISK \\
\hline
\end{tabular}

The Standard of Living of the Workers in a Spanish...

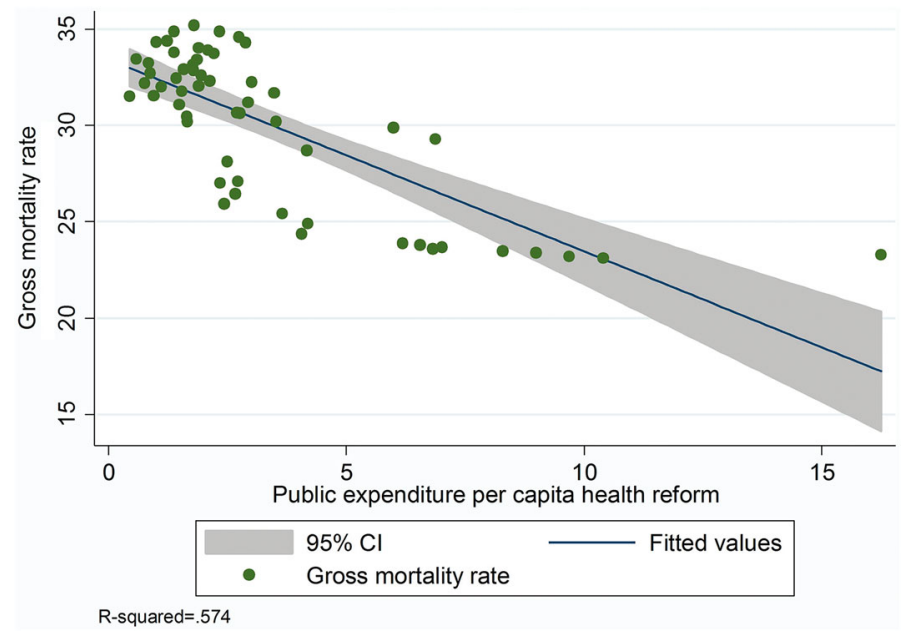

Fig. 7 Mortality and sanitary reform

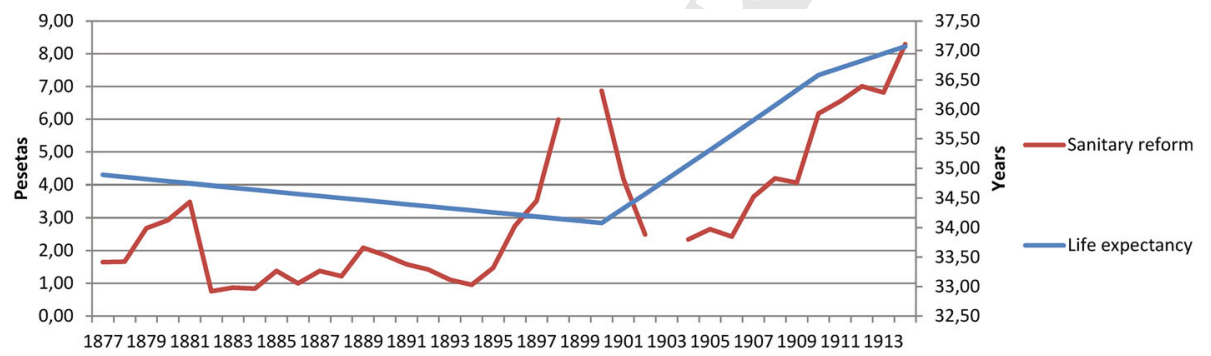

Fig. 8 Life expectancy and and expenditures in sanitary reform in Alcoy (1877-1914)

From the 1870s, hygienists, republicans, socialists and anarchists demanded the municipal authorities of Alcoy to undertake a sanitary reform. This request was rejected until the 1890 s by both conservatives and liberals, the two parties that dominated the local government during the period known in Spain as the Restoration. ${ }^{23}$ These parties opposed the sanitary reform with two arguments based on radical liberalism. The first was that the reform required an increase in taxes and this was counterproductive because it would drain money away from agriculture, industry or trade. The second argument was that the excess death rate in the working class neighbourhoods was a natural consequence of poverty and bad habits of the poor. However, the pressure exerted by the left-wing parties and the coming to local power of councillors of the reformist wing of the liberal party led by José Canalejas explains why this reform was implemented in the $1890 \mathrm{~s}^{24}$

${ }^{23}$ The period known in Spain as the Restoration began in 1876 when a military coup d'état restored the monarchy under Alfonso XIII and ended in 1923 when General Primo de Rivera established the Dictatorship.

${ }^{24}$ García-Gómez (2016) and García-Gómez and Salort (2014) have studied the political reasons why the health reform was delayed until the 1890s. 


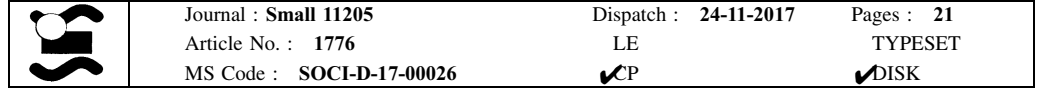

J. J. García-Gómez, A. Escudero Gutierrez

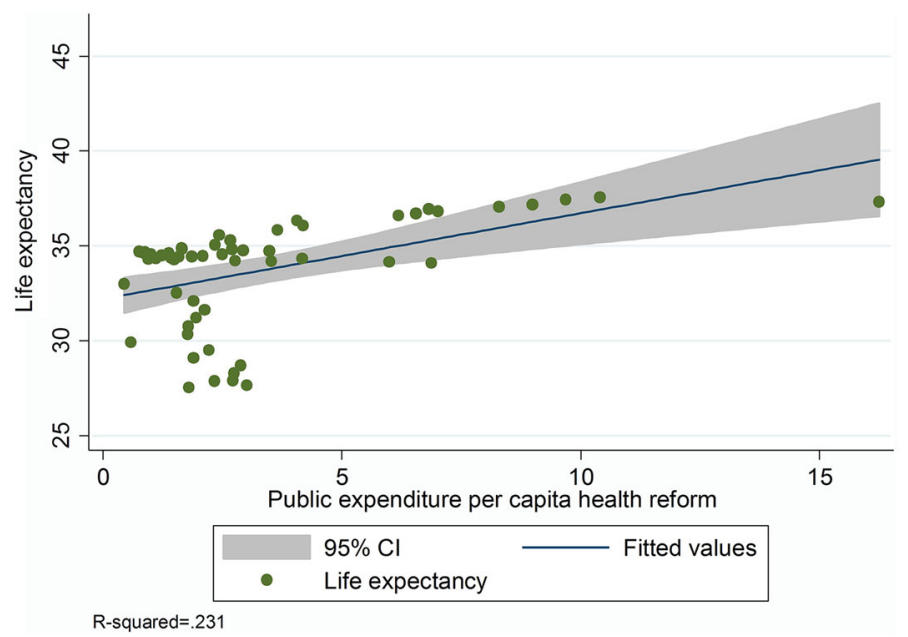

Fig. 9 Life expectancy and sanitary reform

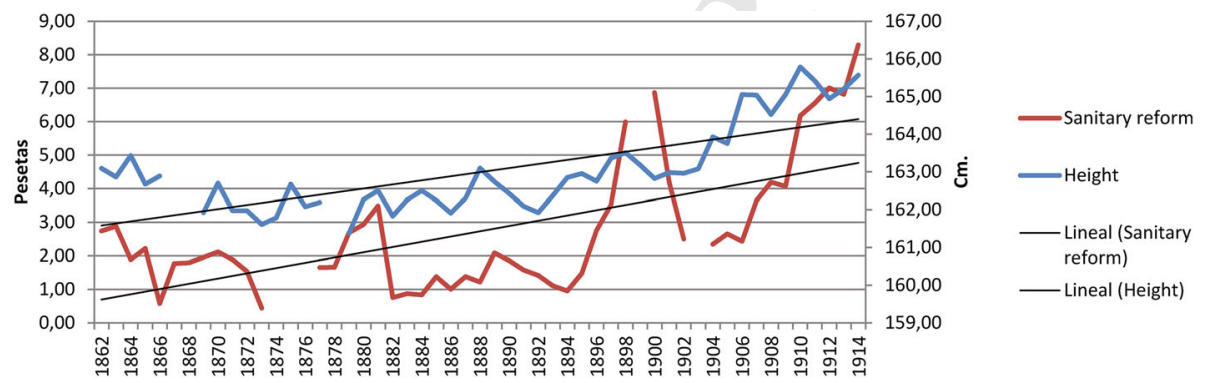

Fig. 10 Height and expenditure in sanitary reform in Alcoy (1862-1914)

We have quantified the sanitary reform using the settlements of the budgets of the local government and by calculating the following expenditure items: water, sewage facilities, street cleaning, woodland, parks, slaughterhouse, municipal doctors, midwives, hospital, urban planning studies and cemetery. ${ }^{25}$ Table 6 contains this information. In Column 1 we can see the cost of the reform in constant pesetas of 1913 and in Column 2 the cost per inhabitant. We can observe that the reform began during the 1890s reaching its greatest impetus between 1906 and 1914.

The sanitary reform contributed to alleviate the above-described market failures which reduced the risk of contracting infectious diseases transmitted by air, water and contaminated food. This can be seen in the following etiological data. Between 1898 and 1900, $60 \%$ of mortality in the town was due to infectious diseases, of which $39 \%$ were air-borne, $15 \%$ were transmitted through water and food and $6 \%$ were caused by other vectors. Then, between 1928 and 1932, deaths caused by infections had fallen to $40 \%$; those caused by air-borne diseases had fallen to $27 \%$; those transmitted through water and food to $9 \%$ and those caused by other vectors had fallen to $4 \%$ (Beneito 1993).

25 The settlements can be found in the Archivo Municipal de Alcoy. 


\begin{tabular}{|l|lcc|}
\hline & Journal : Small 11205 & Dispatch : 24-11-2017 & Pages : 21 \\
Article No. : 1776 & LE & TYPESET \\
MS Code : SOCI-D-17-00026 & CP & DISK \\
\hline
\end{tabular}

The Standard of Living of the Workers in a Spanish...

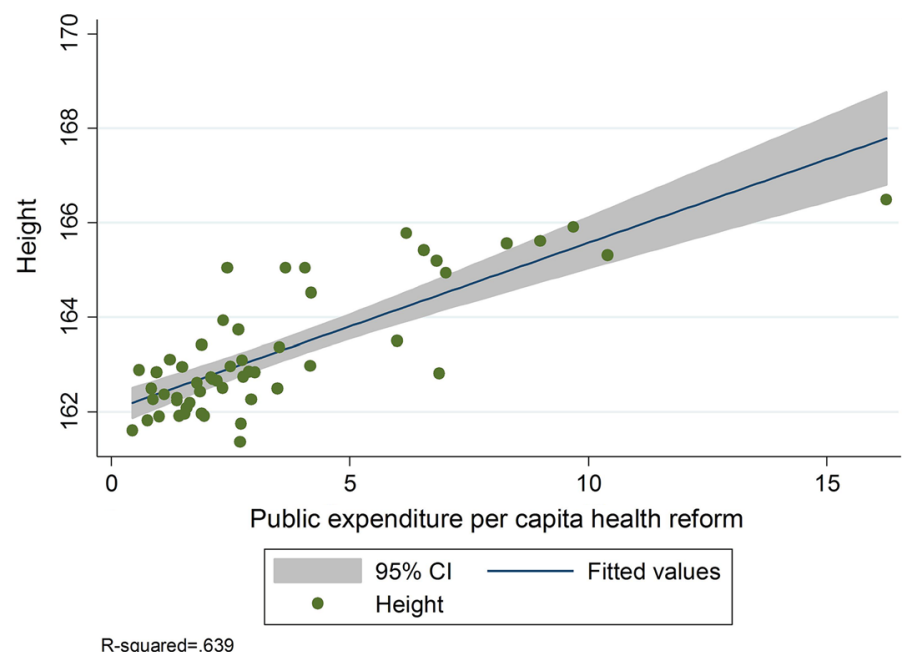

Fig. 11 Height and sanitary reform

It is worth comparing the evolution of the sanitary reform efforts and the mortality indicators. In Fig. 6 we can see the crude mortality rate in Alcoy between 1878 and 1914 and expenditure on sanitary reform per person between the same years. We should point out that we have introduced this second variable with a gap of 5 years as the effects of public spending on health and mortality are not immediate. We can observe that both variables are inversely proportional, which coincides with the hypothesis that sanitary reform could be necessary although not sufficient condition to the reduction in mortality.

Figure 7 shows the statistical correlation between both series. As we can observe, the Pearson's product-moment coefficient is 0.77 with a $p$ value 0.000 , so the correlation is statistically significant with a $1 \%$ confidence.

Figure 8 shows how life expectancy fell between 1877 and 1900, a period in which per capita expenditure on sanitary reform was very low (1877-1894) or when the effects of the higher expenditure were still not visible (1896-1898). We can also observe that both variables grew at the same rate between the beginning of the twentieth century and 1914 .

We find a high correlation between the life expectancy and the sanitary reform expenditures (Fig. 9) as the Pearson's product-moment coefficient is 0.67 and statistically significant with a confidence of $1 \%$.

We will now consider the evolution of the fourth indicator of the standard of living: height. As we can see in Fig. 10, the conscripts born in 1898 had an average height of $1.63 \mathrm{~m}$ while those born in 1930 had an average height of $1.67 \mathrm{~m}$. There are three reasons for this increase in net nutritional input: (a) the higher consumption of calories was now sufficient to cover the energy requirements of the work; (b) the State passed laws that regulated child labour and improved working conditions ${ }^{26}$ and (c) sanitary reform reduced morbidity.

It is worth observing the relationship between sanitary reform and height. Figure 10 suggests that both variables display an upward trend and their correlation coefficient

${ }^{26}$ From the beginning of the twentieth century, the State enacted legislation that improved working conditions: regulation of child and female labour, a reduction in the working day to $9 \mathrm{~h}$ and the Sunday rest law. See Beneito (2003). 


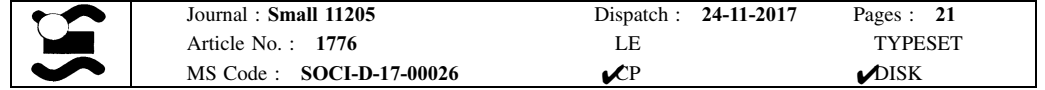

J. J. García-Gómez, A. Escudero Gutierrez

(Fig. 11) is statistically significant (0.73) in the same confidence interval than in the previous correlations.

Based on all of the above, we can maintain that the standard of living of the workers in Alcoy increased in the period from the beginning of the twentieth century to 1930 as observed in the series of real wages, nutrition, life expectancy and height.

\section{Conclusions}

Many studies reveal that it is advisable to analyse the evolution of the standard of living using several indicators as there is no single variable that reflects all of the components of well-being or does so without incurring judgement values. In this article we have studied the standard of living of the workers in Alcoy between 1870 and 1930 using four indicators: real wages, nutrition, mortality and height. The conclusions of the study can be summarised as follows:

Between 1870 and the end of the nineteenth century, real wages and nutrition increased slightly, but life expectancy and height decreased. This "puzzle" can be explained by the "urban penalty" that existed, the high incidence of child labour and the harsh working conditions. Therefore, it seems correct to confirm that the standard of living decreased as the slight increase in consumption of the working class of the town masked the deterioration in health and working conditions reflected in morbidity, life expectancy and height.

This pessimistic panorama changed between the beginning of the twentieth century and 1930. Real wages increased as did nutrition, life expectancy and height. The increase in the well-being of the working class was undoubtedly due to the market (increased productivity and wages), but also to the State intervention. The sanitary reform of the town reduced the market failures that had given rise to the urban penalty and the enactment of several laws that regulated child and adolescent labour contributed to improving the biological standard of living of the workers.

In our opinion, the scenario in Alcoy coincides with the model recently proposed by Floud, Fogel, Harris and Chul Hong (2011, op. cit.) for the industrialisation process of the British cities. According to these authors, between 1810 and the mid nineteenth century, real wages increased modestly as did nutrition. However, this slight increase in gross nutritional input was not sufficient to increase net nutritional input due to the harsh conditions of child and adolescent labour and the increase in morbidity related to the urban penalty. After 1870 , better nutrition, the sanitary reform in the cities and the improved working conditions for children and adolescents would explain the decrease in mortality and the increase in height.

Acknowledgements This work has been funded by the Ministry of Economy of the Spanish Government through the Projects HAR2014-56428-C3-1-P, HAR2014-56428-C3-2-P and by Santander Universidades through the Grants Programa Becas Iberoamérica, Jóvenes Profesores e Investigadores y Alumnos de Doctorado. Santander Universidades. España, 2014 and 2014.

\section{References}

Aracil, R., \& García, M. (1974). Industrialització al País Valencià: el cas d'Alcoi. Valencia: Eliseu Climent. Bairoch, P. (1988). Cities and economic development. From the dawn of history to the present. Chicago: The University of Chicago Press. 


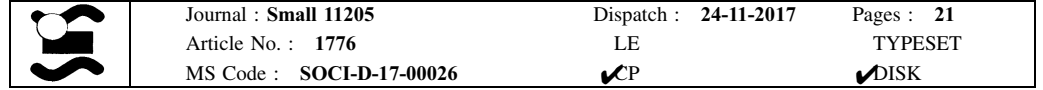

The Standard of Living of the Workers in a Spanish...

Bell, F., \& Millward, R. (1998). Public health expenditures and mortality in England and Wales, 1870-1914. Continuity and Change, 13, 221-249.

Beneito, À. (1993). Comportamiento epidémico y evolución de las causas de defunción en la comarca de $1^{\prime}$ Alcoià-El Comtat. Siglos XIX-XX. Alicante: Unpublished Doctoral thesis.

Beneito, À. (2003). Condicions de vida i salut a Alcoi durant el procés d'industrialització. Valencia: Universitat Politècnica de València.

Cerdá, E. (1967). Monografia sobre la industria papelera. Gráficas Aitana: Alcoy.

Cerdá, E. (1980). Lucha de clases e industrialización. Valencia: Ed. Almudín.

Clark, G. (2001). Farm wages and living standards in the industrial revolution: England, 1670-1869. Economic History Review, 54, 477-505.

Crafts, N. F. R. (1985). English workers' real wages during the industrial revolution: Some remaining problems. Journal of Economic History, 45, 139-144.

Crafts, N. F. R. (1997). Some dimensions of the quality of life during the British industrial revolution. Economic History Review, 50(4), 617-639.

Cuevas, J. (1999). Los orígenes financieros de la industria de Alcoi (1770-1900). Alicante: Unpublished Doctoral thesis.

Dávila, J. M. (1993). Alcoy: desarrollo urbano y planeamiento. Alicante: Servicio de Publicaciones de la Universidad de Alicante.

Deaton, A. (2013). The great escape: Health, wealth, and the origins of inequality. Princeton: Princeton University Press.

Engerman, S. (1976). The Height of U.S. Slaves. Local Population Studies, 16, 45-50.

Escudero, A., \& Nicolau, R. (2014). Urban penalty: nuevas hipótesis y caso español (1860-1923). Historia Social, 80, 9-23.

Escudero, A., \& Simón, H. (2003). El bienestar en España: una perspectiva de largo plazo (1850-1992). Revista de Historia Económica, 3, 525-565.

Eveleth, P. B., \& Tanner, J. M. (1976). Worldwide variation in human growth. Cambridge: Cambridge University Press.

Feinstein, C. H. (1998). Pessimism perpetuated: Real wages and the standard of living in Britain during and after the industrial revolution. Journal of Economic History, 58, 625-658.

Flinn, M. W. (1974). Trends in real wagers, 1750-1850. Economic history review, 2nd series. 27, 3, 395413.

Floud, R., Fogel, R. W., Harris, B., \& Hong, C. (2011). The changing body. Health, nutrition and human development in the western world since 1700. Cambridge: Cambridge University Press.

Floud, R., Fogel, R. W., Harris, B., \& Hong, S. C. (Eds.). (2014). Health, mortality and the standard of living in Europe and North America since 1700. Cheltenham: Edward Elgar Publishing.

Floud, R., \& Harris, B. (1997). Health, height and welfare: Britain 1700-1980. In R. Steckel \& R. Floud (Eds.), Health and welfare during industrialization (pp. 91-126). Chicago: Chicago University Press.

Fogel, R. W. (1989). Without consent or contract: The rise and fall of American Slavery. New York: W. W. Norton and Company.

Fogel, R. W., \& Engerman, S. L. (1974). Time on the cross. The economics of American Negro Slavery. Boston-Toronto: Little, Brown and Company.

Fogel, R. W., Engerman, S. L., \& Trussell, J. (1982). Exploring the uses of data on height: the analysis of long-term trends in nutrition, labor, welfare and labor productivity. Social Science History, 6, 401-421.

Fraser, H. (1993). Municipal socialism and social policy. In R. J. Morris \& R. Rodger (Eds.), The Victorian city (pp. 258-280). London: Longman.

García-Gómez, J. J. (2013). El nivel de vida de los trabajadores de Alcoy (1836-1936). Unpublished doctoral thesis. University of Alicante.

García-Gómez, J. J. (2016). Urban penalty en España: el caso de Alcoy (1857-1930). Historia Industrial, 63, 49-78.

García-Gómez, J. J., \& Salort, S. (2014). La reforma sanitaria en Alcoi (1836-1914): Industrialización, urbanización, fallos de mercado e intervención pública. Historia Social, 80, 95-112.

Gutiérrez, M. (2011). Papel de fumar y mercado exterior: la historia de un éxito. In J. Catalán, J. A. Miranda, \& R. Ramón-Muñoz (Eds.), Distritos y clústeres en la Europa del sur (pp. 37-56). Madrid: LID Editorial Empresarial.

Haines, M. (2001). The urban mortality transition in the United States, 1800-1940. Annales de Démographie Historique, 101(1), 33-64.

Haines, M. (2004). Growing incomes, shrinking people-Can economic development be hazardous to your health? Historical evidence for the United States, England, and the Netherlands in the nineteenth century. Social Science History, 28(2), 249-270. 


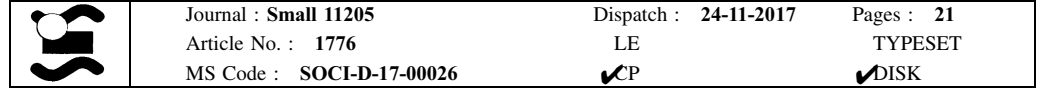

J. J. García-Gómez, A. Escudero Gutierrez

482

483

484

485

486

487

488

489

490

491

492

493

494

495

496

497

498

499

500

501

502

503

504

505

506

507

508

509

510

511

512

513

514

515

516

517

518

519

520

521

522

523

524

525

526

527

528

529

530

531

532

533

534

535

536

537

538

539

540

Harris, B. (2004). The origins of the British Welfare State Society, State and Social Welfare in England and Wales, 1800-1945. Basingstoke: Palgrave Macmillan.

Horlings, E., \& Smits, J. P. (1998). The quality of life in the Netherlands: 1800-1913. Experiments in measurement and aggregation. In J. Komlos \& J. Baten (Eds.), Studies on biological standard of living in comparative perspective (pp. 321-343). Stuttgart: Franz Steiner Verlag.

Kearns, G. (1988). The urban penalty and the population history of England. In A. Brandström \& L. G. Tederbrand (Eds.), Society, Health and Population during the Demographic Transition (pp. 213235). Stockholm: Almqvist and Wiksell International.

Kearns, G. (1991). Biology, class, and the urban penalti. In G. Kearns \& C. J. Withers (Eds.), Urbanising Britain: Essays on class and community in the nineteenth century (pp. 12-30). Cambridge: Cambridge University Press.

Komlos, J., \& Baten, J. (1998). The biological standard of living in comparative perspective. Stuttgart: Franz Steiner.

Krugman, P., Wells, R., \& Graddy, K. (2007). Economics (European ed.). New York: Worth Publishers.

Lana Berasaín, J. M. (2005). Aproximación a los salarios reales en la Navarra rural, 1785-1945. VIII Congreso de la Asociación Española de Historia Económica. http://www.usc.es/es/congresos/histec05/ a1.jsp.

Lindert, P., \& Williamson, J. (1983). English workers living standards during the industrial revolution: A new look. Economic History Review, 36(1), 1-25.

Luckin, B. (2000). Pollution in the city. In M. Daunton (Ed.), The Cambridge urban history of Britain, 1840 1950 (Vol. III, pp. 207-228). Cambridge: Cambridge University Press.

Maluquer, J. (2006). La paradisíaca estabilidad de la anteguerra. Elaboración de un índice de precios de consumo en España, 1830-1936. Revista de Historia Económica, 24(2), 333-382.

Martínez-Carrión, J. M., \& Puche, J. (2011). La evolución de la estatura en Francia y en España, 1770-2000. Balance historiográfico y nuevas evidencias. Dynamis, 31(2), 153-176.

Meier, G. M. (1980). Leading issues in economic development. Oxford: Oxford University Press.

Molina de Dios, R. (2003). Treball intensiu, treballadors polivalents. (Treball, salaris i cost de la vida, Mallorca, 1860-1936). Mallorca: Govern de les Illes Balears.

Mooney, G. (1994). The geography of mortality decline in Victorian London. Liverpool: Liverpool University Press.

Moreno Lázaro, J. (2006). El nivel de vida en la España atrasada entre 1800 y 1936. El caso de Palencia. Investigaciones de Historia Económica, 4, 9-50.

Morris, M. D. (1979). Measuring the condition of the world's poor. The Physical Quality of Life Index. New York: Overseas Development Council.

Myrdal, G. (1974). Contribución a una teoría más realista del crecimiento y el desarrollo económico. Trimestre Económico, 161, 217-229.

Nadal, J., (dir.). (2003). Atlas de la industrialización de España, 1750-2000. Barcelona: Crítica.

Nicolau, R. (2005). Población, salud y actividad. In A. Carreras \& X. Tafunell (Eds.), Estadísticas históricas de España (siglos XIX y XX) (pp. 77-154). Bilbao: Fundación BBVA.

Nordhaus, W., \& Tobin, J. (1973). Is growth obsolete? In M. Moss (Ed.), The measurement of economic and social performance (pp. 509-564). New York: Columbia University Press.

Pérez Castroviejo, P. (2006). Poder adquisitivo y calidad de vida de los trabajadores vizcaínos, 1876-1936. Revista de Historia Industrial, 30(1), 103-143.

Popkin, B. M. (1993). Nutrition patterns and transitions. Population and Development Review, 19, $138-157$.

Preston, S. H., \& van de Walle, E. (1978). Urban French mortality in the nineteenth century. Population Studies, 32, 275-297.

Puche Gil, J. (2009). Evolución de los niveles de vida biológicos en la Comunidad Valenciana, 1840-1948. Unpublished Doctoral thesis.

Pujol, J., \& Cussó, X. (2014). La transición nutricional en Europa occidental, 1865-2000: una nueva aproximación. Historia Social, 80, 133-155.

Reher, D. S. (1990). Urbanization and demographic behaviour in Spain, 1860-1930. In A. Woude et al. (Eds.), Urbanization in history: A process of dynamic interactions (pp. 282-299). Oxford: Clarendon Press.

Samuelson, P. A. (1983). Economía. Madrid: Mac Graw-Hill.

Schofield, R., Reher, D. S., \& Bideau, A. (Eds.). (1991). The decline of mortality in Europe. Oxford: Claredon Press.

Scholliers, P. (Ed.). (1989). Real wages in 19th and 20th century Europe. Historical and comparative perspectives. Oxford: Berg.

Sen, A. (1993). The quality of life. Oxford: Clarendon Press. 


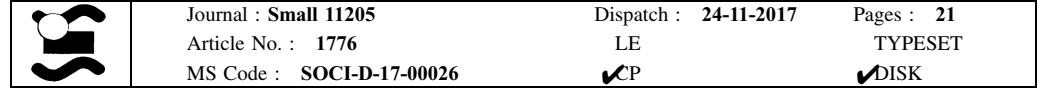

The Standard of Living of the Workers in a Spanish...

541

542

543

544

545

546

547

548

549

550

551

552

553

554

555

556

557

558

559

560

561

562

563

564

565

566

567

568

569

570

571

572

573

574

575

576

577

578

579

580

581

582

583

Sheard, S., \& Power, H. (Eds.). (2000). Body and city: histories of urban public health. Historical Urban Studies. Aldershot: Ashgate.

Smith, L. B., Rosen, K. T., \& Fallis, G. (1988). Recent developments in economic models of housing markets. Journal of Economic Literature, 26(1), 29-64.

Steckel, R. (1995). Stature and the standard of living. Journal of Economic Literature, 33(4), 1903-1940.

Steckel, R., \& Floud, R. (Eds.). (1997). Health and welfare during industrialization. Chicago: University of Chicago Press.

Stiglitz, J. E. (1993). Economics. New York: W.W. Norton \& Company.

Stiglitz, J. E., Sen, A., \& Fitoussi, J. P. (2010). Mismeasuring our lives. New York: The New Press.

Szreter, S. (2002a). A central role for local government? The example of late Victorian Britain. History \& Policy. http://www.historyandpolicy.org/.

Szreter, S. (2002b). The relationship between public health and social change. American Journal of Public Health, 92(5), 722-725.

Szreter, S. (2002c). Health, class, place, and politics: Social capital and collective provision in Britain. Contemporary British History, 16, 27-57.

Szreter, S. (2005). Health and wealth: Studies in history and policy. Rochester studies in medical history. Rochester: Rochester University Press.

Szreter, S., \& Mooney, G. (1998). Urbanization, mortality, and the standard of living debate: New estimates of the expectation of live in nineteenth century British cities. Economic History Review, 51, 84-112.

Tanner, J. M. (1990). Foetus into man: Physical growth from conception to maturity. Cambridge: Harvard University Press.

Torró Gil, L. L. (1994a). Sobre la protoindustrialització. Reflexions a partir d'un cas local, Alcoi (segles XVI-XIX). Afers. Fulls de recerca i pensament, 19, 661-680.

Torró Gil, L. L. (1994b). Los inicios de la mecanización en la industria lanera de Alcoi. Revista de Historia Industrial, 11(6), 133-142.

Torró Gil, L. L. (2004). Procedimientos técnicos y conflictividad gremial: el ancho de los peines de los telares alcoyanos (1590-1797). Revista de Historia Industrial, 25, 165-182.

Vazquez, E., Camaño, F., Silvi, J., \& Roca, A. (2003). La tabla de vida: una técnica para resumir la mortalidad y la sobrevivencia. Boletín epidemiológico Organización Mundial de la Salud, 24(4), 6-10.

Vögele, J. (1998). Urban mortality change in Britain and Germany, 1870-1913. Liverpool: Liverpool University Press.

Vögele, J. (2000). Urbanization and the urban mortality change in imperial Germany. Health \& Place, 6, 4155.

Woods, R. (2000). The demography of victorian England and Wales. Cambridge: Cambridge University Press.

Woods, R. (2003). Urban-rural mortality differentials. An unresolved debate. Population and Development Review, 29, 29-46.

Woods, R., \& Woodward, J. (Eds.). (1984). Urban disease \& mortality in nineteenth-century England. London: Batsford Academic and Educational.

Woodward, J. (1984). Medicine and the city: the nineteenth century experience. In R. Woods \& J. Woodward (Eds.), Urban disease and mortality in nineteenth-century England (pp. 65-78). London: Batsford. 